\title{
Kültürel Peyzajın Korunması ve Turizm İlişkisi Bağlamında Yerel Halkın Görüşleri: Ihlara Vadisi Örneği
}

\section{The Opinions of Local People in Context of Relations Between Cultural Landscape Protection and Tourism: Case of Ihlara Valley}

\author{
Funda VARNACI UZUN ${ }^{1}$, Mehmet SOMUNCU ${ }^{2}$ \\ ${ }^{1}$ Aksaray Üniversitesi, Eğitim Fakültesi İlköğretim Bölümü, Aksaray \\ ${ }^{2}$ Ankara Üniversitesi, Dil ve Tarih-Coğrafya Fakültesi, Coğrafya Bölümü, Ankara
}

\begin{abstract}
Özet: Bu araştırmada, Ihlara Vadisi'nde yaşayan yerel halkın vadideki kültürel peyzaj değerlerinin korunması ve bölgede devam eden turizm faaliyetlerinin ekonomik ve sosyal etkileri konusundaki görüşlerini değerlendirmek amaçlanmaktadır. Araştırmada, nitel araştırma yöntemi kullanılmıştır. Araştırma kapsaminda, Ihlara Vadisi'nde bulunan Ihlara Kasabast, Selime Beldesi, Belisirma ve Yaprakhisar köylerindeki yerel halk ile görüşme yapılmıştır. Araştırmada, yarı yapılandırılmış görüşme formu yardımıyla toplam 44 kişi ile görüşülmüş̧ür. Görüşme verileri, Nvivo 9.0 ortamında içerik analizi yapılarak değerlendirilmiştir. Araştırma sonuçlarına göre; yerel halk alandaki kültürel peyzaj değerlerinin korunması hususunda olumlu görüsse sahiptir. Bunun yanında; yerel halk bölgede devam eden turizm faaliyetlerinden pay alamamaktadır. Ancak; yerel halk turizmin gelişimine karşı olumlu tutuma sahiptir ve turizme katılım konusunda isteklidir.

Anahtar kelimeler: Ihlara Vadisi, Yerel halk, Sürdürülebilir turizm, Kültürel peyzaj, Turizmin etkileri.
\end{abstract}

\begin{abstract}
In the present study, the aim is to investigate the opinions of local people about the protection of cultural landscape values in the valley and the social and economic effects of ongoing tourism activities. The study employs qualitative research method. Within the framework of the study, interviews were made with the local people living in Ihlara town, Selime province, Belistrma and Yaprakhisar villages located in the valley. In the study, through a semi-structured interview form, 44 local people were interviewed. The interview data were evaluated through content analysis by means of Nvivo 9.0. According to findings of the study, the local people have positive opinions about the protection of cultural landscape in the region. In addition, local people think that they do not have enough share from ongoing tourism activities in the region. However, the local people have positive opinions about the development of tourism and they are willing to participate in tourism activities.
\end{abstract}

Key words: Ihlara Valley, Local people, Sustainable tourism, Cultural landscape, Effects of tourism.

\section{Giriș}

Bir bölgede, turizmin gelişimi ekonomik ve sosyal olarak çok iyi imkanlar sağlıyor olsa da, aynı gelişimin çevresel değerler üzerinde güçlü bir baskısının olduğu da bir gerçektir (Bestard vd., 2007). $\mathrm{Bu}$ nedenle turizm planlamalarında son yıllarda, sürdürülebilir turizme olan ilgi gittikçe artmaktadır (Aronsson, 2000; Eagles vd., 2002). Dünya Turizm Örgütü, sürdürülebilir turizmi yerel halkın ve turistlerin ihtiyaçları karşılanırken, gelecek için fırsatların da artırılması ve korunması şeklinde tanımlamaktadır (WTO, 1993).

Turizmin gelişiminden olumlu ya da olumsuz olarak etkilenen gruplara paydaş adi verilmektedir (Aas vd., 2005; Nicholas vd., 2009). Sürdürülebilir turizm yaklaşımında, bir bölgedeki turizm faaliyetlerinden etkilenen en önemli paydaşlar; yerel ve ulusal yöneticiler, turizm sektöründekiler, sivil toplum kuruluşları, yerel halk, medya ve turistlerdir (Swarbrooke, 1999). Bazı kaynaklara göre ise;

\footnotetext{
$\mathrm{Bu}$ araştırma devam etmekte olan doktora tezinden üretilmiştir.
} 


\section{F. Varnacı Uzun ve M. Somuncu}

yerel halk turizmin geliştiği alanlardaki en önemli paydaş konumundadır (Aas vd., 2005; Swarbrooke, 1999; Byrd vd., 2009; Yoon, 2002). Yerel halkı turizm gelişim sürecine dahil etmek, bu konudaki görüş ve önerilerini almak, fikir alışverişinde bulunmak ve gelecekteki turizm gelişmesini teşvik yönünde karşılıklı fikir alışverişi yapmak, yerel halkın karar merkezlerini etkileyebilmesi ve kendilerini turizmin bir parçası olarak hissetmeleri açısından oldukça önemlidir (Avcıkurt, 2003). Yerel halkın algılaması veya tercihi turizm gelişim politika ve programlarını desteklemediği durumlarda, turizm gelişimine yönelik programlar uygulamada başarısız veya etkisiz olabilir. Doğal ve kültürel kaynak değerlerine duyarlı sürdürülebilir turizmin geliştirilebilmesi için yerel halkın turizm konusundaki tutum ve algılarının değerlendirilmesi gerekmektedir (Akova, 2006). Sürdürülebilir turizm uygulamalarında, yerel halk, turizm planlamaları ile ilgili kurumlarla işbirliği içinde olmalı ve yerel halkın turizme katılımına imkan sağlanmalıdır (Akşit, 2007). Bir turizm planının başarısı, yerel toplumun desteği olmadan gerçekleşemez. Yerel halk, turisti kabul ettiği ölçüde turist, bulunduğu mekândan memnuniyet hissedecektir (Gürsoy ve Rutherford, 2004). Toplumun yapısı, turistlerin alanda kalış süreleri ve turizme ekonomik bağımlılık gibi bazı sosyal ve kültürel faktörler yerel halkın turizme karşı tutumunu etkilemektedir. Turizme ekonomik olarak bağımlılık, yerel halkın turizmi kabullenme seviyesini artırmaktadır. (Besculides vd., 2002).

Bir alan turistik destinasyon konumuna geldiğinde, o bölgede yaşayan yerel halkın yaşamında çeşitli değişiklikler olmaktadır (Gürsoy ve Rutherford, 2004). Sürdürülebilir turizm yaklaşımında turizm ile birlikte yaşanan değişim, genel itibariyle ekonomik, sosyal ve çevresel olarak üç bileşen şeklinde açıklanmaktadır (Butler, 1999).

Turizm ekonomik gelişim ve hayat kalitesinin gelişimi anlamında büyük bir potansiyel taşımaktadır. İş olanaklarının çeşitlenmesi, turistik mekanların açılması, gelir düzeyinin artışı turizmin taşıdığı potansiyellerden bazılarıdır. Ancak turizm ile birlikte yerel halkın yaşamında bazı olumsuz değişimler de olur. Kalabalık, suç oranının artması, yaşamın pahalılaşması, turistler ile çatışma bunlardan bazılarıdır (Andereck vd., 2005). Sürdürülebilir turizm ise, ekonomik açıdan bazı prensipleri içermektedir. Bu prensipler; turizmden zarar ve maliyetleri en düşük duruma getirirken, faydanın en yüksek ve en iyi durumda olması, yerel halkın, özellikle düşük sosyo-ekonomik düzeye sahip toplumlarda, turizmin yararlarından eşit düzeyde yararlanması, yerel toplumdaki yerel ekonomilerin desteklenmesi şeklinde özetlenebilir (Nicholas vd., 2009).

Turizmin gelişiminden yerel halk ekonomik gelir sağlamakla birlikte, bir süre sonra çevresel problemlerle karşı karşıya kalmaktadır. Çünkü turizm genellikle doğal ve kültürel anlamda hassas alanlarda gelişmektedir. Bu nedenle yerel halkın turizme karşı tutum ve düşüncelerinde çevresel değerler ile ekonomik gelişimin birbirine bağımlı olduğunu göz önünde bulundurmalıdır. Yapılan araştırmaların bazılarında yerel halk turizmin ekonomik ve sosyal etkileri için olumlu görüşe sahipken çevresel etkileri anlamında olumsuz görüşe sahiptir (Andereck vd., 2005; Bestard ve Nadal, 2007). Kültürel peyzaj, yerel halkın üzerinde yaşadığı bölgenin geçmiş ve yaşayan geleneklerini barındırması bakımından önem taşımaktadır ${ }^{*}$ (UNESCO, 1998). Kültürel peyzaj öğeleri bulunduğu alandaki en önemli turistik ürün olarak turizmin gelişmesini sağlarken, yerel halk da bu gelişimden ekonomik ve sosyal olarak etkilenmektedir (Kaya, 2002; UNESCO, 1999). Kültürel peyzajın sağladığı ekonomik firsatlara karşın, peyzajın bozulması gibi bir tehdidi de göz önünde bulundurmak gerekmektedir. $\mathrm{Bu}$ tehditleri en aza indirmek ve koruma yaklaşımını geliştirmek için çeşitli paydaşlar arasında iletişim ve işbirliğine ihtiyaç vardır (Aas vd., 2005; Besculides vd., 2002). Sürdürülebilir turizm ise; genel olarak sadece turizmin sürdürülebilirliği için değil aynı zamanda yaşamın devamlılı̆̆ için gerekli olan çevrenin korunmasını içermektedir (Nicholas vd., 2009). Gebhard vd. (2008)'e göre, sürdürülebilir turizm, ekonomik fayda için doğal ve kültürel kaynak kullanımına izin verirken; kaynaklar üzerindeki

\footnotetext{
* Kültürel Peyzaj; UNESCO Dünya Kültürel Mirası Komitesi’nce “doğa ve insanoğlunun ortak çalışmasının yansıtılması” şeklinde tanımlanmaktadır. Dünya Mirası Komitesi tarafından 1992 yılında olağanüstü dünya değerleri kriterlerine uygun olduğu konusundaki ortak karar ile Dünya Mirası kategorilerine eklenmiştir.
} 
olumsuz etkileri en aza indirgeyen ziyaretçi yönetimi ve turizmden elde edilen gelirin doğal ve kültürel kaynakların korunması için kullanılması yaklaşımlarıyla; kaynakların bozulmamasını ve korunmasını garanti etmektedir (Somuncu ve Yiğit, 2009).

Kültürel gelişim, kültürlerarası paylaşım, iletişim ve eğitim seviyesi gibi sosyal bileşenler sürdürülebilir turizm yaklaşımında en az dikkati çeken bölümdür. Çünkü sürdürülebilir turizmin sosyo-kültürel etkileri çoğunlukla soyuttur ve daha yavaş hızda gerçekleşmektedir. Sosyo-kültürel sürdürülebilirlik genel olarak toplumun kültür fabrikası konumundaki yerel halkı kapsamaktadır. Sürdürülebilir turizmin gelişiminde, bu üç sürdürülebilirlik ilkesinin karışımı; çevresel olarak duyarlı, ekonomik olarak katma değer sağlayıcı ve sosyal olarak eşitlikçi olmalıdır. Sürdürülebilir turizmde temel hedef, birliktelik enerjisi oluşturabilmek için aralarında bir denge kurmaktır (Nicholas vd., 2009).

Literatürde; yerel halkın turizm ve turizm etkileri konusundaki görüşlerini araştıran pek çok çalışma bulunmaktadır. $\mathrm{Bu}$ çalışmalarda; turizmin etkilerinin yerel halk tarafından algılanması (Alaeddinoğlu, 2007; Baykan, 2007; Akova, 2006), yerel halkın turizmin gelişimine yönelik tutumu (Choi vd., 2010; Lepp, 2007; Haley vd., 2005; Zamani-Farahani ve Musa, 2008), turizmin toplum üzerindeki etkileri konusunda yerel halk görüşleri (Andereck vd., 2005; Emekli, 2001; Özdemir ve Kervankıran, 2011; Çetin, 2010; Williams and Lawson, 2001), yerel halkın turizmin ekonomik, sosyal ve çevresel bakımdan olumlu ve olumsuz etkilerine yönelik tutumları (Besculides vd., 2002; Deery vd., 2012; Bestard, 2007; Dal ve Baysan, 2007; Dyre, 2010; Jimura, 2011; Kuvan ve Akan, 2005), yerel halkın turizmi desteklemesi ve turizme katılma isteğinde etkili olan faktörler (Dyer vd., 2007; Gürsoy vd., 2002; Stone and Stone, 2010; Gürsoy ve Rutherford, 2004), korunan alanlarda turizmin toplum üzerindeki etkisi (Strickland-Munro vd., 2010); miras turizminin gelişiminde sosyal kimlik ve toplumun rolü (Ballesteros ve Ramirez, 2007), turizmin gelişiminden yerel kimliklerin etkilenme durumu (Uslu ve Kiper, 2006), turizmin etkileri ve turistik destinasyonun rekabet gücü konularında farklı paydaş görüşlerinin karşılaştırılması (Byrd vd., 2009; Yoon, 2002) ve yerel halkı turizmin karar vericilerine dahil etme süreci (Aas vd., 2005) gibi konular incelenmiştir.

Ihlara Vadisi'ndeki yerel halkın bu bölgedeki turizm faaliyetlerine ilişkin görüşleri, bu bölgede gerçekleştirilebilecek sürdürülebilir turizm uygulamalarına, temel paydaşlardan yerel halkı da dahil etmek bakımından önemlidir. Bu nedenle araştırmada, yerel halkın bölgedeki turizme ilişkin görüşleri değerlendirilirken, sürdürülebilir turizmin temel bileşenleri olan, ekonomik etkiler, sosyal etkiler ve çevresel koruma bileşenleri çerçevesinde değerlendirme yapılmıştır.

Bu araştırmada; Ihlara Vadisi'nde bulunan Ihlara Kasabası, Selime Beldesi, Belisırma Köyü ve Yaprakhisar Köyü'nde yaşamakta olan yerel halkın, Ihlara Vadisi'ndeki turizm faaliyetlerinin ekonomik ve sosyal etkisi ile alandaki kültürel peyzaj değerlerinin korunmasına ilişkin görüşleri nasildır? sorusuna yanıt aranmaktadır.

\section{Araştırma Alanı}

Araştırma alanını; Aksaray İli sınırlarındaki 14 km uzunluğundaki Ihlara Vadisi'nde bulunan Ihlara Kasabası, Selime Beldesi, Belisırma Köyü ve Yaprakhisar Köyü oluşturmaktadır (Şekil 1). 


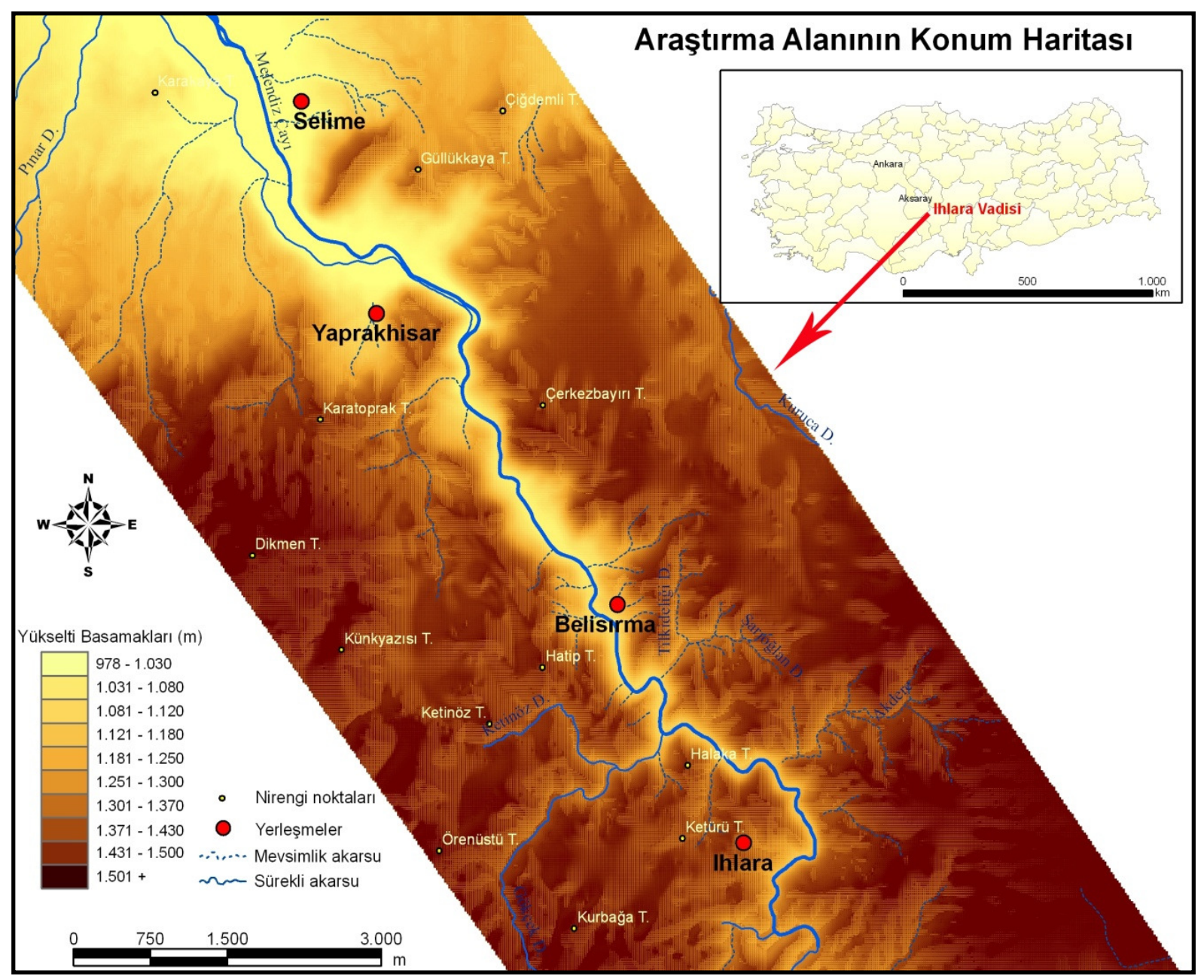

Şekil 1. Araştırma alanının konum haritası.

Ihlara Vadisi, Hasan Dağı volkanizması ile şekillenen ve Hıristiyanlığın ilk dönemlerinden itibaren doğal yapının insanlar tarafından hem barınma hem de ibadet yeri olarak kullanıldığı bir bölgedir. Vadi bu özelliği ile önemli bir kültürel peyzaj alanıdır. Yöre insanı ilk yerleşimlerden günümüze kadar çevresindeki kayaları oluşturan tüf malzemenin kolay oyulabilme özelliğinden sürekli olarak yararlanmıştır. Yüzyıllar boyu çevredeki yerleşim jeolojik oluşum nedeniyle kaya içi yaşamı biçiminde devam etmiştir. Bölgede bol miktarda bulunan ve kolaylıkla işlenebilen yöresel taş konut yapımında da ustaca kullanılmıştır (Gürler, 2007). Dünya Mirası Komitesi’nin 2001 yılında Finlandiya'da düzenlenen toplantısı sonucundaki raporunda, maddi kültürel peyzaj değerleri sınıflandırılmıştır (Fowler, 2003). Bu değerlerden; insan yapımı mağaralar, mağara resimleri, evler, manastırlar - kiliseler ve sığınma alanlarının örnekleri Ihlara Vadisi ve çevresinde bulunmaktadır (Foto 1-2), (Varnac1 Uzun ve Somuncu, 2010).

Ihlara Vadisi ve vadi içindeki köyler 1990 yılında Bakanlar Kurulu kararı ile ilan edilen Ihlara Özel Çevre Koruma Bölgesi sınırlarında yer almaktadır. Ancak, vadi kültürel peyzaj özellikleri bakımından benzer özelliklere sahip ve mekansal olarak da yakın konumda olduğu Göreme Milli Parkı ve Kapadokya Kayalık Sitleri dünya Mirası Alanı sinırlarında bulunmamaktadır (Varnacı Uzun ve Somuncu, 2010). 


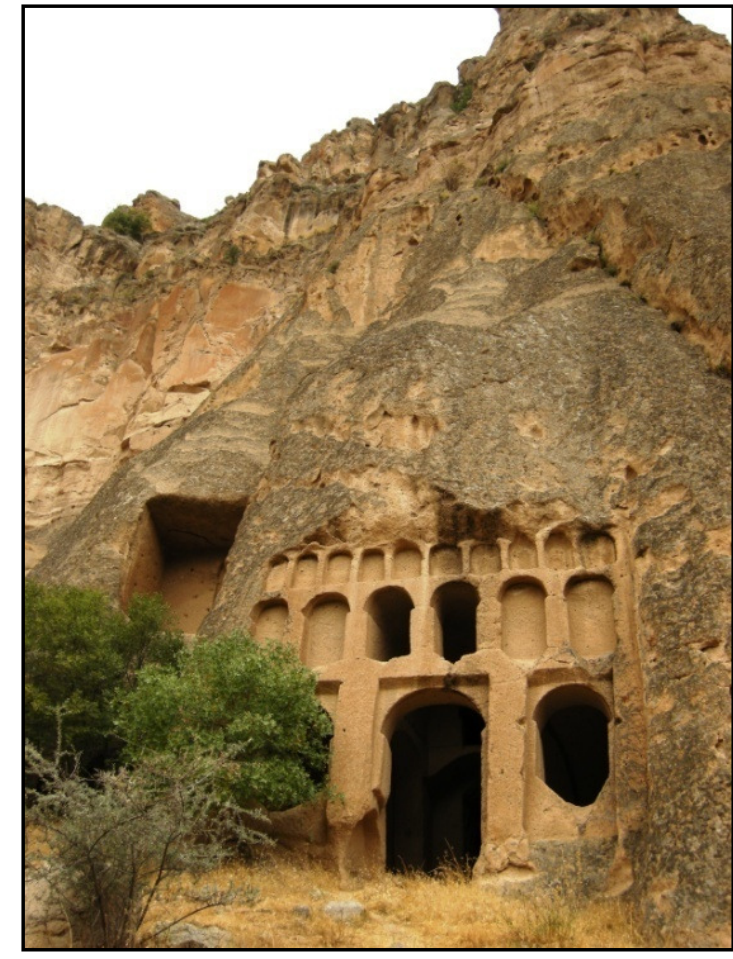

Foto 1. Vadi duvarına oyulmuş kiliselerden bir örnek.

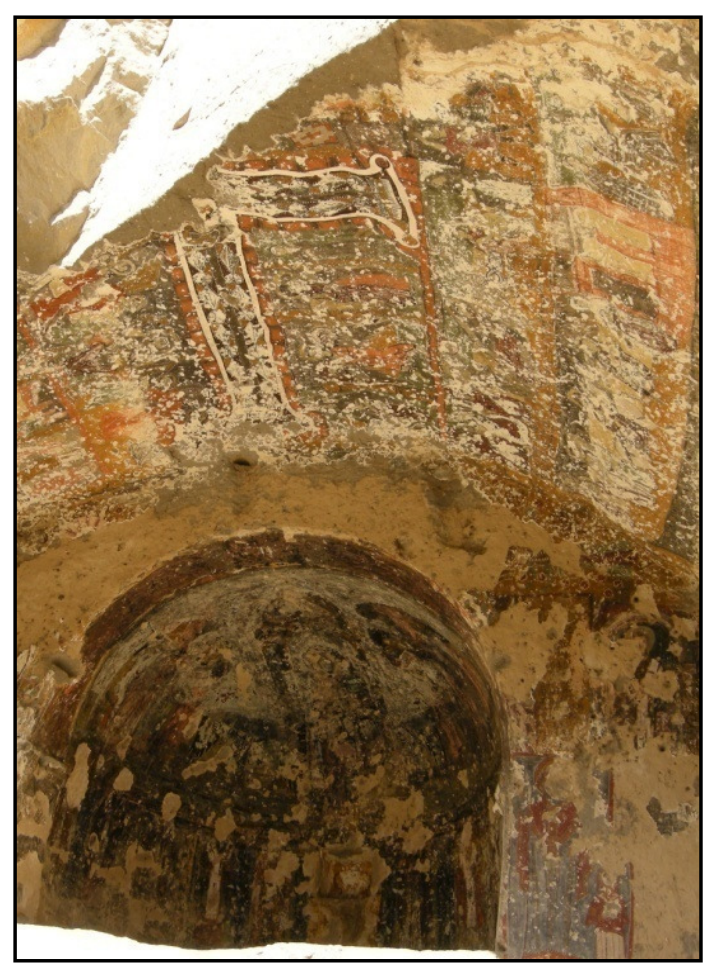

Foto 2. Kilise duvarlarındaki fresklerden bir örnek.

Ihlara Vadisi, sahip olduğu doğal görünüm ve kültürel peyzaj özellikleri sebebiyle yılda ortalama 200.000 kişi tarafindan ziyaret edilmektedir (Aksaray Kültür ve Turizm Müdürlüğü, 2008, 2009, 2010). Ihlara Vadisi'nin başlangıcında yer alan Ihlara Kasabası'nın nüfusu 2645; vadi içinde yer alan Belisırma Köyü’nün nüfusu 499, Yaprakhisar Köyü’nün nüfusu 438 iken, vadinin sonunda yer alan Selime Beldesi'nin nüfusu 2245'tir (TÜIIK, 2011). Bu nüfus verilerine göre, Ihlara Vadisi'nde gerçekleşen turizm faaliyetlerinden etkilenmesi beklenen 5827 kişilik yerel halk nüfusuna karşıllk, bu bölgelerde yer alan konaklama tesisleri yatak kapasitesi ancak 250 kişi civarındadır. Ayrıca, konaklama tesisleri pansiyon şeklinde ve alt yapıları yetersiz durumdadır. Bölgeyi, günübirlik olarak ziyaret eden turistlere hizmet veren sadece altı adet restaurant bulunmaktadır.

\section{Materyal ve Yöntem}

Araştırmada, nitel araştırma yöntemi kullanılmıştır. Araştırma alanında bulunan Ihlara Kasabası, Belisırma Köyü, Selime Beldesi ve Yaprakhisar Köyü’nden rastgele örneklem yöntemiyle seçilmiş toplam 44 kişiyle yarı yapılandırılmış görüşme formu yardımıyla görüşme gerçekleştirilmiştir. Görüşmeler, Ekim 2011 döneminde dört farklı arazi çalışmasında gerçekleştirilmiştir. Görüşmelerin, 29'u yüz yüze görüşme tekniği ile yapılırken, 4'ü odak grup görüşmesi şeklinde gerçekleştirilmiştir. Odak grup görüşmelerinde toplam 15 kişi ile görüşülmüştür. Görüşmelerde, video ya da ses kayıt cihazı ile kayda izin verilmediği için görüşme süresince not alınarak görüşmeler tamamlanmıştır.

Görüşmeler sırasında alınan notlar, her bir görüşme için ayrı dosya oluşturacak şekilde MS Office Word yazılımı kullanılarak bilgisayar ortamına aktarılmıştır.

Görüşmelerin analizi için Nvivo 9.0 nitel veri analizi programı kullanılmıştır. Görüşme verileri 29'u yüz yüze, 4'ü odak grup görüşmesi olacak şekilde toplam 33 veri dosyası üzerinden analiz edilmiştir. Öncelikle dosyalar her bir görüşmeci için YH1, YH2 vb. olarak isimlendirilmiş ve Nvivo 


\section{F. Varnacı Uzun ve M. Somuncu}

9.0 ortamına aktarılmıştır. Daha sonra, yapılan içerik analizi sonucunda katılımcıların görüşleri önceden belirlenen temalar altında toplanacak şekilde kodlanmıştır. Her bir görüşme dosyası içinde kodlara karşl1ık gelebilecek metinler belirlenmiştir. Kodlama işlemi sonucunda, her bir kodun işaretlenme frekanslarını içeren modeller oluşturulmuştur. Ayrıca, sayısal verileri desteklemek amacıyla, kelime ağaçları (word tree) ve doğrudan alıntılara yer verilerek sonuçlar yorumlanmıştır.

\section{Bulgular}

Araştırma alanında, 44 kişi ile yarı yapılandırılmış görüşme formu yardımı ile görüşme gerçekleştirilmiştir. Görüşmelerin; \%38,6's1 Ihlara Kasabası, \%22,7'si Selime Beldesi, \%20,5'i Belisırma Köyü ve \%18,2'si Yaprakhisar Köyü'nde yapılmıştır. Görüşme yapılan bireylerin $\% 52,3$ 'ünü bayanlar, \%47,7'sini erkekler oluşturmaktadır. Yaş gruplarına göre dağılıma bakıldığında \%52,3'ünü 35-54 yaş arasında bireylerin oluşturduğu görülmektedir. Görüşülen bireyler arasında, çiftçiler \%43,2 oranı ile en büyük grubu oluşturmaktadır (Çizelge 1).

Çizelge 1. Araştırma alanında görüşme yapılan bireylerin demografik özellikleri.

\begin{tabular}{|c|c|c|}
\hline Görüşme yapılan yer & Kişi sayısı & $\%$ \\
\hline Ihlara Kasabası & 17 & 38,6 \\
\hline Selime Beldesi & 10 & 22,7 \\
\hline Belisırma Köyü & 9 & 20,5 \\
\hline Yaprakhisar Köyü & 8 & 18,2 \\
\hline Toplam & 44 & 100,0 \\
\hline Cinsiyet & Kişi sayısı & $\%$ \\
\hline Erkek & 21 & 47,7 \\
\hline Kadın & 23 & 52,3 \\
\hline Toplam & 44 & 100,0 \\
\hline Yaş grupları & Kişi sayısı & $\%$ \\
\hline $18-34$ & 8 & 18,2 \\
\hline $35-54$ & 23 & 52,3 \\
\hline $55+$ & 13 & 29,5 \\
\hline Toplam & 44 & 100,0 \\
\hline Meslek & Kişi sayısı & $\%$ \\
\hline Çiftçi & 19 & 43,2 \\
\hline Emekli & 8 & 18,2 \\
\hline Ev hanımı & 7 & 15,9 \\
\hline Muhtar & 1 & 2,3 \\
\hline Boyac1 & 3 & 6,8 \\
\hline Garson & 2 & 4,5 \\
\hline Şoför & 1 & 2,3 \\
\hline Öğretmen & 1 & 2,3 \\
\hline İşsiz & 2 & 4,5 \\
\hline Toplam & 44 & 100,0 \\
\hline
\end{tabular}

Araştırma kapsamında görüşülen bireylerin görüşleri; turizmin ekonomik etkisi, sosyal etkisi ve kültürel peyzaj değerlerinin korunması temaları altında değerlendirilmiştir. 


\subsection{Turizmin Ekonomik Etkisine İlişskin Yerel Halk Görüşlerinin Değerlendirilmesi}

Bu bölümde, Ihlara Vadisi'nde turizmin yerel halka ekonomik etkileri, yerel halkın görüşleri doğrultusunda değerlendirilecektir. Yerel halk görüşleri doğrultusunda, turizmin ekonomik katkılarına

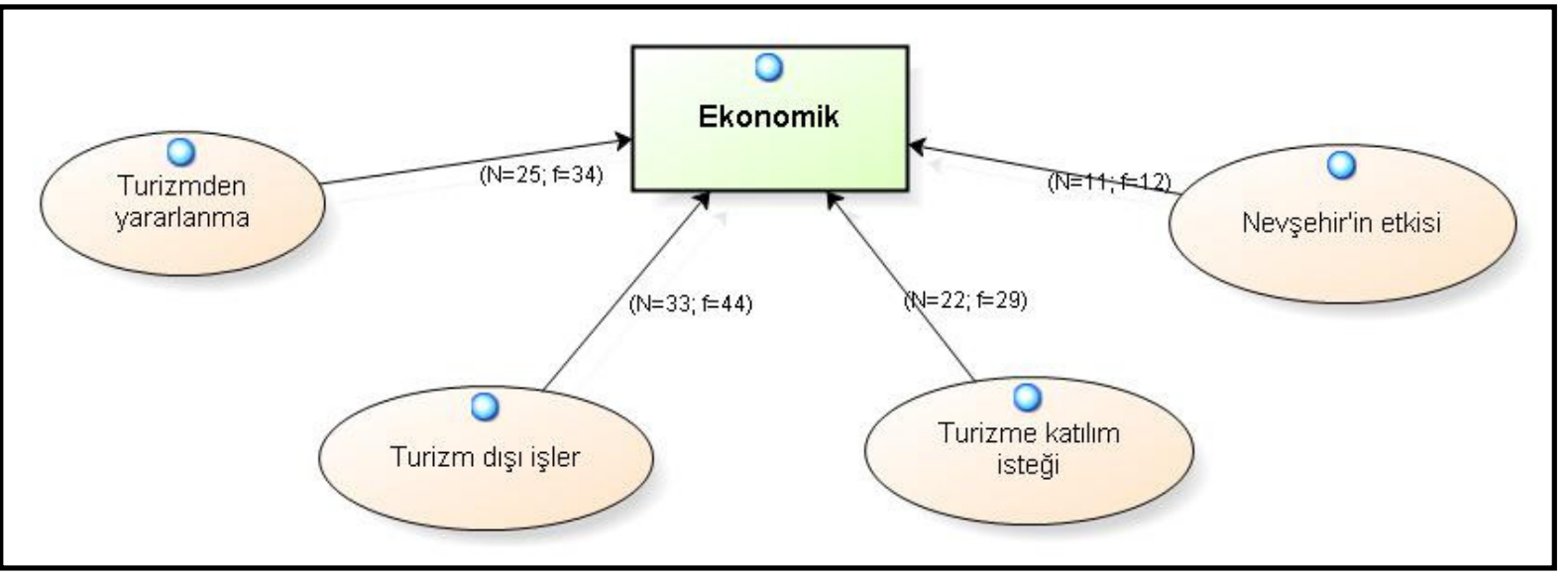

ilişkin tema altında, turizmden yararlanma, turizm dışı işlerde çalışma, turizme katılım isteği ve Nevşehir' in etkisi kodları ortaya çıkmıştır (Şekil 2).

Şekil 2. Turizmin ekonomik etkisine ilişkin model.

Araştırma alanı, mekânsal olarak ve kültürel peyzaj değerleri bakımından Göreme ve çevresine yakındır. Ancak, yerel halkın turizme katılımı ve turizmden pay alması bakımından Göreme ve çevresinin çok gerisinde kalmaktadır (Varnacı Uzun ve Somuncu, 2010). Şekil 2'de görüldüğü gibi, yapılan görüşmelerden $25^{\prime}$ inde, 34 defa yerel halk turizmden pay alamadığını belirten cümleler kullanılmıştır. Yerel halk, bu durumu aşağıdaki ifadelerle dile getirmektedir:

"Buraya da turistler geliyor ama kalmiyor, hemen gidiyor. Bizim buradaki bakkallardan hiçbir şey satın almazlar, kahvelerde bir şey içmezler. Bizim köyde uygun yer çok ama turistler için kimse bir dükkan açmıyor. Satış yapamayacaklarını düşünüyorlar. Çocuklarımızın bazıları turizm mezunu ama işsiz. Burada çalışabilecekleri pansiyon, otel ya da restaurant yok.” (YH1, Ihlara Kasabası, Erkek, Boyac1, 35-54 yaş)

"Bizim burada turizm gelişmiyor. Turizmden para kazanan kimse yok. Çok turist geliyor Nevşehir'den ama köylümüze bir faydası yok. Kimse çalışamıyor turizmde. Sadece bir kaç lokanta var nehrin klylsinda. Oralara da her turist girmiyor, rehberleri isterse."(YH11, Selime Beldesi, Bayan, Ev hanımı, 18-34 yaş).

"Bizim buraya turistler gelir gelmesine de, bize bir faydası olmaz. Kalabalı halinde gelirler. Bir tek büyük kiliseyi gezerler, giderler. Ne bir su alırlar ne bir çay içerler. Biz sadece kalabalı̆̆ izleriz." (YH25, Selime Beldesi, Erkek, Çiftçi, 35-54 yaş).

"Hafta sonları otobüsleri park etmeye yer olmaz. Merdiven kalabalı olur. Ama turistler vadide bir saat dolaştıktan sonra gidiyorlar. Köye bir faydası olmuyor. Vadinin başındaki restaurant kazanıyor, onun işletmecisi de köyden değil zaten." (YH4, Ihlara Kasabası, Erkek, Boyac1, 18-34 yaş).

"Turistler çok gelir buraya, kayaların dibindeki mağaraların fotoğraflarını çekiyorlar gidiyorlar. Biz sadece turistin kalabalığını görüyoruz, bize hiç faydası yok.” (YH29, Yaprakhisar Köyü, Erkek, Emekli, 55+ yaş).

"Ne düşünelim. Biz hiç yararlanamıyoruz ki. Her hafta turist gelir bizim köye. Ama bize ne faydası olacak." (YH23, Belisırma Köyü, Bayan, Çiftçi, 18-34 yaş). 


\section{F. Varnacı Uzun ve M. Somuncu}

Yerel halk görüşmelerinden aktarılan doğrudan alıntılarda da görüldüğü gibi yerel halk, köylerine sürekli ve kalabalık gruplar halinde turistlerin geldiğini ama kendilerinin turizmden ekonomik olarak fayda sağlayamadıklarını dile getirmektedir.

Yerel halk görüşmelerde turizm ile ilgili olarak, "bize bir faydast yok", "bize bir yararı yok" ifadelerini sıklıkla kullanmaktadır. Şekil 3 ve 4'te yararı ve faydası kelimelerinin görüşmelerdeki kullanım frekanslarına bağlı olarak oluşturulan kelime ağaçları (word tree), yerel halkın turizmden pay alamadığını doğrulamaktadır.

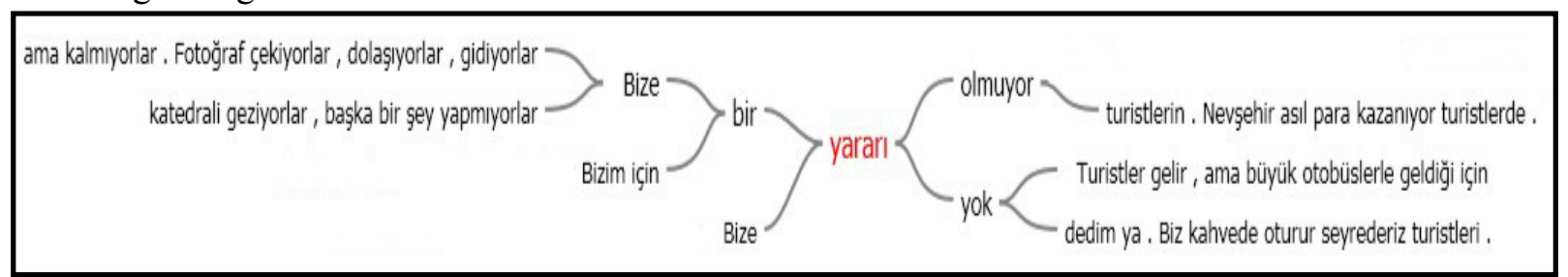

Şekil 3. "Yarar" kelimesine ait kelime ağac1.

Fayda ve yarar kavramları ile ilişkilendirilen cümleler, turistlerin Ihlara Vadisi'ni kısa süreli olarak ziyaret ettiklerini ve yerel halkın turizmden kazanç sağlayamadığını göstermektedir. Turistlerin, sadece bir kısmı ziyaretlerinde Belisırma Köyü'ndeki dört restauranttan birinde yemek yemektedir. Bu durumda da, yerel halktan sadece birkaç kişi turizmden faydalanmaktadır.

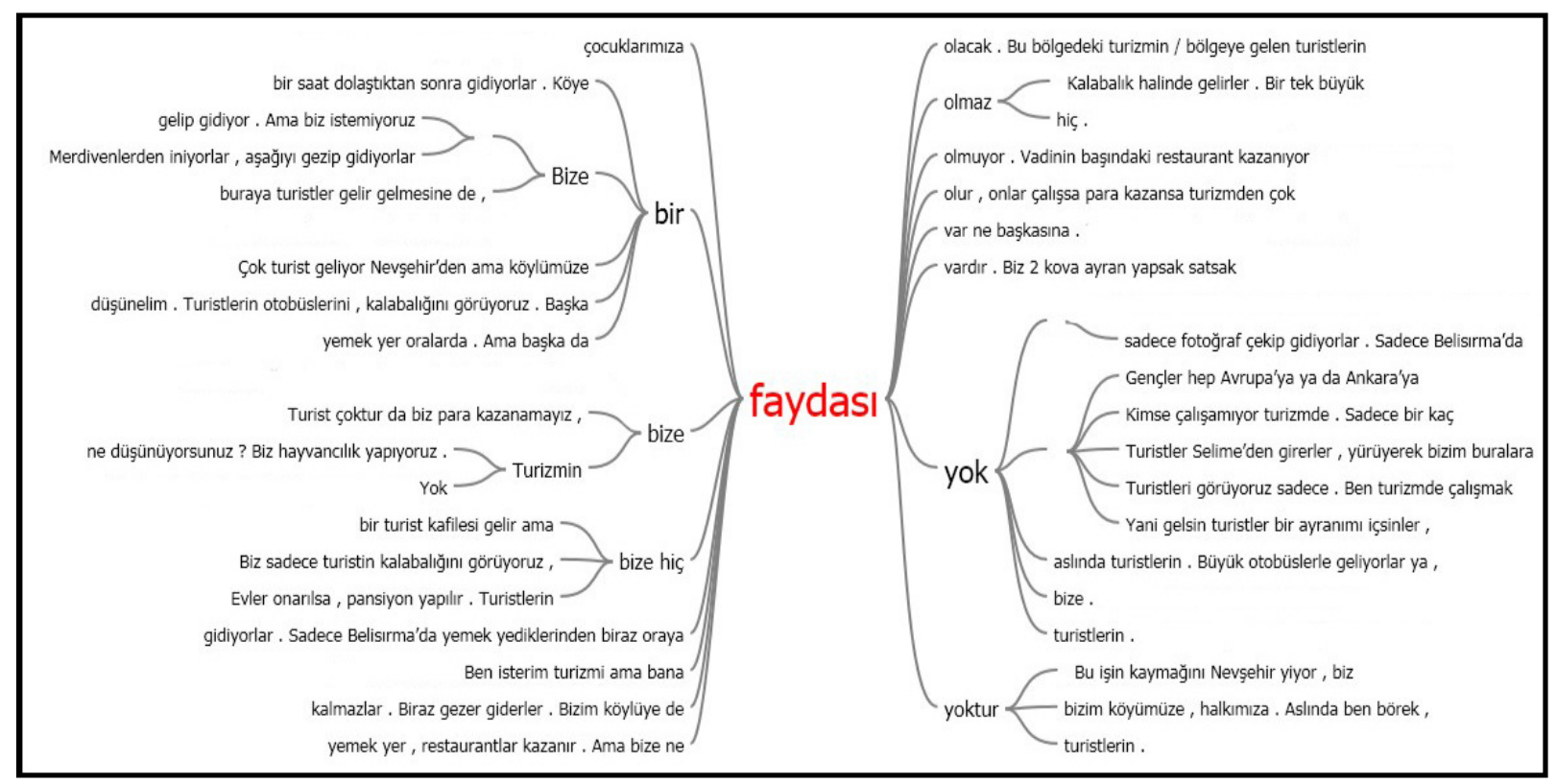

Şekil 4. "Fayda" kelimesine ait kelime ağacı.

Ihlara Vadisi'ni ziyaret eden turistlerin vadiyi kısa süreli ziyaret etmeleri, vadi içinde ya da çevresinde konaklama yapmamaları ve yerel halka ekonomik katkı sağlayabilecek yöresel ürün satın alma vb. gibi diğer turistik faaliyetlerde bulunmamaları yerel halkın turizmden pay alamaması sonucunu ortaya çıkarmaktadır.

Alanda devam eden turizm faaliyetlerine rağmen yerel halk turizm dışı işlerde çalışmaktadır (Varnacı Uzun ve Somuncu, 2010). Tablo 1'de görüldüğü gibi görüşülen bireylerin \%43,2 gibi büyük bir bölümü çiftçilik yapmaktadır. Bireylerin sadece 2'si garsondur ve turizm ile ilgili bir işte 
çalışmaktadır. Görüşülen bireyler, turizm dışındaki işlerden kazanç sağladıkları şu sözlerle belirtmektedir:

“Tarım yapıyoruz. Geçimlik olarak; patates, fasulye gibi ürünler yetiştiriyoruz." (YH3, Belisırma Köyü, Bayan, 35-54 yaş).

"Ben ev hanımıyım, beyim boyacılı yapıyor. Bahçemiz var, onu ekiyorum kendimize kadar." (YH11, Selime Beldesi, Bayan, 18-34 yaş).

"Çiftçilik yapıyoruz. Onu da kendimize kadar, fazlasını götüremiyoruz şehre, araba kiralamak pahal.." (YH21, Ihlara Kasabas1, Bayan, 35-54 yaş).

"Gençler hep Avrupa'ya ya da Ankara'ya gidiyor çalışmaya, burada yaşlılar kalıyor. Ancak ekersek bir yiyeceğimiz oluyor, yoksa tandırda pişirip kuru ekmek yiyoruz. Hiçbir gelirimiz yok. "(YH30, Yaprakhisar Köyü, Bayan, 18-34 yaş).

Alıntılardan da anlaşılacağı gibi yerel halk genel olarak tarımla uğraşmaktadır. Ancak tarım faaliyetlerini de, geçimlik düzeyde gerçekleştirmektedir. Boyacılık yerel halkın sahip olduğu diğer mesleklerdendir. Halkın büyük bölümü de, görüşmecilerin de belirttiği gibi, büyük şehirlere ya da başka ülkelere iş amaçlı olarak göç etmektedir.

Araştırmada yerel halkın turizme katılma isteği olup olmadığını ve katılması halinde ne gibi işler yapabileceklerini tespit etmek amac1yla halka, "Turizm ile ilgili işlerde çalışmak istiyor musunuz?" ve "Turizmden gelir elde etmek için neler yapabilirsiniz?" soruları yöneltilmiştir.

Yapılan değerlendirmeler sonucunda; görüşmecilerin 22'si 29 defa turizm ile ilgili işlerde çalışmak ve turizmden kazanç sağlamak istediğini ifade etmiştir (Şekil 2). Yerel halk, turizme katılma isteklerini görüşmelerde şu şekilde dile getirmektedir:

“Turizmle uğraşmak isterim tabiî ki, yöresel ürünleri satarız.” (YH13, Belisırma Köyü, Bayan, Ev hanımı, 18-34 yaş).

"El işi yapıyoruz, tezgahlarda onları satarı. Turistler sever öyle şeyleri. Ama şimdi nerde satacağız, yerimiz yok." (YH23, Belisırma Köyü, Bayan, Çiftçi, 18-34 yaş).

"Halı dokumacılık yapabilirim. Turistlere halı satabiliriz. Ben tek başıma çekinirim de köyden başka kadınlar da yapsa beraber olabilir. ”(YH3, Belisırma Köyü, Bayan, Çiftçi, 35-54 yaş).

"İsteriz tabiî ki turizmle uğraşmak. Herkes ister, üretir satar. Turistik eşya yerleri olsa, el işi satarız. Çekirdek, fasulye, elma satarız. "(YH32, Ihlara Kasabas1, Bayan, Çiftçi, 35-54 yaş).

"Yerel halk duyarlı, turizmde çalışmak istiyor ama tek başına yatırım yapamaz. Bilgisi yok." (YH33, Ihlara Kasabas1, Erkek, Muhtar, 35-54 yaş).

“Rehberlik yapmak isterim.” (YH4, Ihlara Kasabası, Erkek, Boyac1, 18-34 yaş).

"İsterim, çocuklarım için isterim. Ev pansiyonculuğu yaparı, turistleri gezdiririz." (YH9, Ihlara Kasabası, Erkek, Emekli, 55+ yaş).

"Rehberlik yapabilirim. Ben çocukluğumda çobanlı yaparken bütün mağaralara girdim çıktım. Hepsini avucumun içi gibi bilirim. Turistleri gezdiren rehberlerden daha çok bilirim. Bizim köylüler de bilir. Biz turistleri gezdirebiliriz. Turistlere taşımacıllk hizmeti de verebilirim." (YH5, Belisırma Köyü, Erkek, Şoför, 35-54 yaş).

Örneklerden de anlaşılacağı gibi; yerel halk turizme katılım konusunda oldukça isteklidir. Turizmden kazanç elde etmek için, yöresel ürünlerin satışını yapabileceklerini sıklıkla dile getirmektedirler. Bunun yanında, yöresel rehberlik ve ev pansiyonculuğu da yapmak istedikleri işler arasındadır. Ancak yerel halk, turizme yatırım yapma ve girişimcilik konusunda yeterli bilgiye sahip değildir. Ayrıca, özellikle bayanların turizme katılım konusunda teşvik edilmeye ihtiyacı vardır. 
Görüşmelerde öne çıkan bir başka konu ise; Nevşehir'in Ihlara Vadisi'ndeki yerel halkın turizmden pay almasını olumsuz yönde etkilediğidir. Görüşmecilerden 11 kişi, 12 defa Nevşehir ya da Kapadokya ile ilgili olumsuz tutuma sahip olduklarını belirten cümleler kullanmıştır (Şekil 2). Bu cümlelerden örnekler şu şekilde sıralanabilir:

"Kapadokya kaymağını yiyor bu işin. Turizmden onlar çok kazanıyor. Bize bir şey kalmıyor. Oteller orada, turistler gece orada kalıyor, en büyük pay da onlara kallyor böylece. Buralarda (Ihlara çevresi) kalınmaz, yemek yenmez diye anlatırlarmış turistlere." (YH2, Selime Beldesi, Erkek, İssiz, 35-54 yaş).

"Kapadokya bizi olumsuz etkiliyor. Turistler orda kaliyor, orda yemek yiyor. Bize bir şey kalmıyor. Bize gelince boş gezip gidiyorlar." (YH21, Ihlara Kasabas1, Bayan, Çiftçi, 35-54 yaş).

"Nevşehir turizmin kaymağını yiyor biz tozunu. Buradaki pansiyonlar Nevşehir'den gelen rehberlere yalvarma ile turistlerin sadece 1-2 gece konaklamasın sağlayabiliyorlar. Ama normalde Nevşehir'de 60-70 liraya konaklarken burada 20-25 lira arası ancak. Nevşehir'den turlar buraya getiriyor, burada sadece öğle yemeği yiyip gidiyorlar. Ama halkın \%1 'i bile bundan faydalanmıyor." (YH33, Ihlara Kasabas1, Erkek, Muhtar, 35-54 yaş).

“Bu işin kaymă̆ını Nevşehir yiyor, biz kahvede oturup seyrediyoruz. Aksaray'da valilik de bir şey yapmıyor. Nevşehir'den getirirlerse turist görüyor buraları, kendi haline birakırsan bilmez ki turist. Nevşsehir'i bilir, Kapadokya'yı bilir turistler." (YH7, Selime Beldesi, Erkek, Emekli, 55+ yaş).

"Aslında burası Kapadokya'nın bir parçasıdır. Ama bunu kimse dile getirmiyor. Hep geri planda kalıyor burast." (YH13, Belisırma Köyü, Bayan, Ev hanımı, 18-34 yaş).

"Burası Kapadokya'ya bağlı aslında ama buraya daha az turist geliyor. Turlarla turistleri buraya getiriyorlar." (YH24, Belisırma Köyü, Bayan, Garson, 18-34 yaş).

Yerel halkın da dile getirdiği gibi; Nevşehir, Göreme ve Ürgüp'te turizm altyapısının gelişmiş olması sebebiyle turistler konaklama ve yeme-içme faaliyetlerini, bir başka deyişle seyahat harcamalarını Nevşehir ve çevresinde gerçekleştirmektedir. Buna karşıllk, Ihlara Vadisi'ndeki yerleşimlerde konaklama ve diğer faaliyetleri gerçekleştirebilecek alt yapının yetersiz olması sebebiyle yerel halk turizmden fayda sağlayamamaktadır. Yerel halk bu durumu, Ihlara Vadisi'nin aslında Kapadokya'nın bir parçası olmasına rağmen geri planda kalmasına, Nevşehir'den sayıca az turistin bu bölgeye getirilmesine ve vadide uzun süreli ziyarete imkân verilmemesine bağlamaktadır. Nevşehir'deki halkın turizmden büyük kazanç elde ettiğini ve kendilerine ise pay bırakılmadığını, bu nedenle de Kapadokya'nın olumsuz etkisi olduğunu görüşmelerde ifade etmektedirler.

\subsection{Turizmin Sosyal Yapıya Etkisine İlişkin Yerel Halk Görüşlerinin Değerlendirilmesi}

Ihlara Vadisi'nde yaşayan yerel halkın alanda turizmin gelişimi ve turizmin kendilerine sosyal anlamda katkısı, yerel halkın görüşleri doğrultusunda incelendiğinde; turizme karşı olumlu-olumsuz tutum, turizmin sosyal gelişime katkısı ve eğitim kodları ortaya çıkmıştır (Şekil 5).

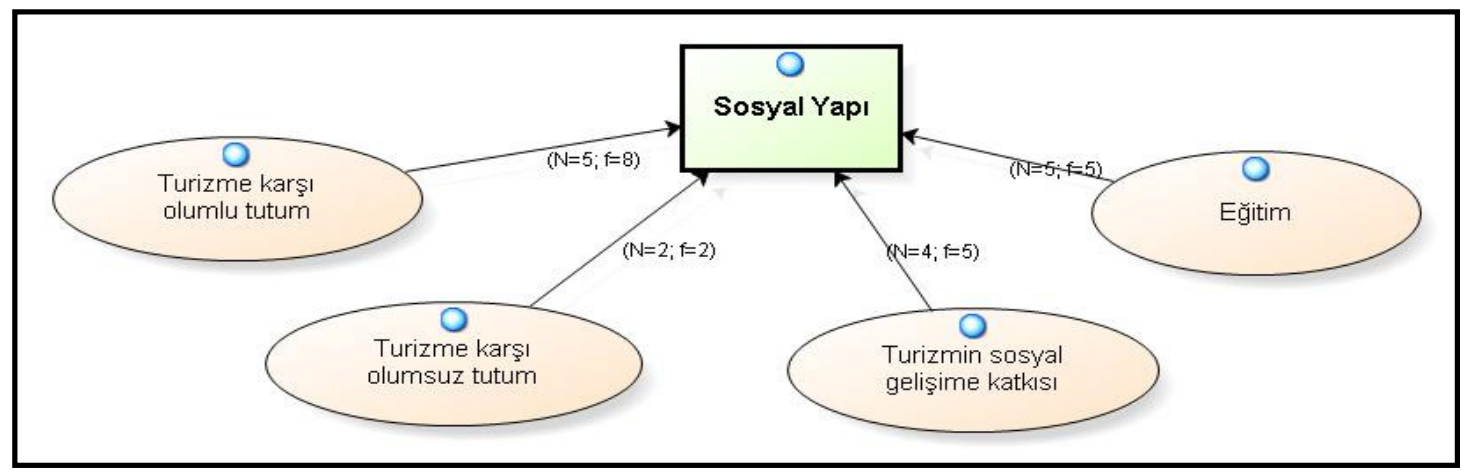

Şekil 5. Turizmin sosyal etkilerine ilişkin model. 
Yerel halk ile yapılan görüşmeler sonucunda, görüşmecilerin $5^{\prime} \mathrm{i} 8$ defa turizmin gelişimi konusunda olumlu tutuma sahip olduğunu dile getirmiştir (Şekil 5. Olumlu düşünceye sahip olanlar bu durumu şu sözlerle ifade etmiştir:

"Bizim köyümüze turist gelmesinden memnunuz. Turistler geliyor geziyor. Kalaballk oluyor buralar. Farkl insanları görüyoruz, yabancıları görüyoruz."(YH12, Selime Beldesi, Bayan, Çiftçi, 35-54 yaş).

"Halk turizmi, turistleri kabullenmiş durumda, çatışma yok aramızda. "(YH33, Ihlara Kasabası, Erkek, Muhtar, 35-54 yaş).

“Bence turizm olumlu bir şey. Para kazanıyoruz. ”(YH24, Belisırma Köyü, Bayan, Garson, 1834 yaş).

Yerel halkın turizme karşı olumlu düşüncelerine karşılık sadece 2 kişi, olumsuz düşünceye sahip olduğunu belirtmiştir (Şekil 5):

"Ama turistler gençlerimizin aklını çeliyor. Klyafetleri bizim toplumumuza uygun değil." (YH27, Ihlara Kasabası, Bayan, Çiftçi, 36-60 yaş).

"Turizm iyi değildir. Kalabalık oluyor buralar. Pisliklerini çevreye, nehire atıyorlar." (YH22, Ihlara Kasabası, Bayan, İssiz, 60+ yaş).

Turizmin olumsuz olduğunu düşünenler, turistlerin kıyafetlerinin yerel halkın geleneksel yapısına uygun olmaması ve turistlerin yarattığı çevre kirliliğini sebep göstermişlerdir.

Yapılan görüşmelerde 4 görüşmeci 5 defa turizmin halk1 geliştireceği yönünde düşüncelerini belirtmiştir (Şekil 5). Bu durum aşağıdaki sözlerden anlaşılmaktadır:

"Turistlerin bizim köye gelmesi çok güzel. Yeni insanlar görüyoruz, onların kültürlerini de tanıyoruz. " (YH13, Belisırma Köyü, Bayan, Ev hanımı, 18-34 yaş).

"Turizm bizim için güzel, çallşlyoruz, para kazanıyoruz. Farklı insanlar görüyorum her seferinde. Yabancı dil de konuşuyorum birazcık da olsa. Gelişiyorum." (YH24, Belisırma Köyü, Bayan, Garson, 18-34 yaş).

Görüşmelerin değerlendirilmesi sonucunda yerel halkın turizm faaliyetlerine katılmak istediği ancak bunu nasıl gerçekleştireceğini bilmediği görülmektedir. Bununla birlikte halk, turizme katılım konusunda yönlendirilmeye ve turizm ile ilgili çeşitli alanlarda eğitimler almaya isteklidir. $\mathrm{Bu}$ konudaki isteklerini şu sözlerle vurgulamaktadırlar:

"Şimdi biz turizmden hiç yararlanamiyoruz ya, belediyenin teşviki ile köydeki insanlar toplu halde bilgilendirilse, ĕgitilse turizm ile ilgili işler yapabiliriz. Ürettiklerimizi satartz, pansiyon işletebiliriz.” (YH21, Ihlara Kasabası, Bayan, 35-54 yaş).

"Rehberlik yapmak isterim. Rehberlik eğitimi verilsin, biz turistleri gezdirelim." (YH4, Ihlara Kasabası, Erkek, Boyac1, 18-34 yaş).

"Çalışmak isterim. El sanatları eğitimi verilse, öğrenir, sonra da satışını yapabiliriz. Vadi başında tezgah açılabilir." (YH6, Ihlara Kasabası, Bayan, Ev hanımı, 35-54 yaş).

"İsteriz isteriz. Pansiyon işletmeciliği hakkında bilgi verilse iyi olur. Öğreniriz biz de yaparız." (YH8, Selime Beldesi, Erkek, Emekli, 35-54 yaş).

"Kurslar açılsa turizmle ilgili gider öğreniriz. Elişi eğitimi olabilir mesela. Sonradan bir şeyler yaparız." (YH13, Belisırma Köyü, Bayan, Ev hanımı, 18-34 yaş).

Yerel halk, el sanatları, rehberlik ve pansiyon işletmeciliği alanlarında eğitim almak istemektedir. 


\section{F. Varnacı Uzun ve M. Somuncu}

4.3. Yerel Halkın Alandaki Kültürel Peyzaj Değerlerinin Korunmasına İlişkin Görüşlerinin Değerlendirilmesi

Ihlara Vadisi ve vadi içindeki köyler Ihlara Özel Çevre Koruma Bölgesi kapsamında koruma altındadır. Yerel halkın alandaki kültürel peyzaj değerlerinin korunmasına ilişkin görüşleri koruma isteği ve korumanın yarattığı zarar kodlarına karşı1ık gelecek şekilde değerlendirilmiştir (Şekil 6).

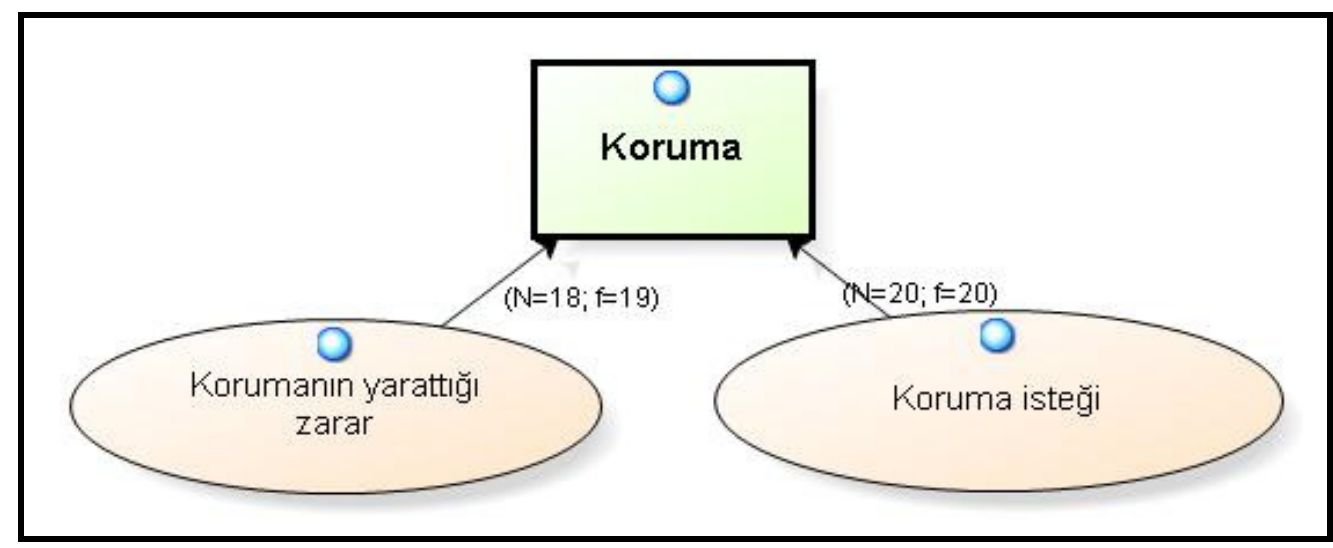

Şekil 6. Kültürel peyzaj değerlerinin korunmasına ilişkin model.

Görüşme yapılan bireylerin 20'si alandaki kültürel peyzaj değerlerinin korunmasının gerekliliği ve korunmasını istediklerine dair görüş belirtmiştir (Şekil 6). Bu konudaki görüşlerden örnekler şu şekilde verilebilir:

"Kültürel mirasın korunması için önemlidir buraların korunması. Ama kimse farkında değil. Biz de bir şey yapamıyoruz. Devletin bir şeyler yapması lazım. Köylüye eğitim verilse, daha çok korur." (YH10, Belisırma Köyü, Erkek, Garson, 18-35 yaş).

"Burası miras olarak görüldüğü için koruma altına alındı." (YH12, Selime Beldesi, Bayan, Çiftçi, 35-54 yaş).

"Eskiden kalan mağaraların içindeki resimleri kırdılar, onların korunmasını isterim. Daha çok turist gelir hem de." (YH21, Ihlara Kasabas1, Bayan, Çiftçi, 35-54 yaş).

"Korunmalıdır. Korunursa daha çok turist gelir. Turist de para kazandırır... Biz bir şey yapmiyoruz, ne yapabiliriz bilmiyoruz ki.. Muhtar da bir şey yapmıyor. Kimse bize bir şey anlatmadı ki.” (YH24, Belisırma Köyü, Bayan, Garson, 18-34 yaş).

"Korunmalı tabii ki. Korunursa iyi olur, çocuklarıma da kalır." (YH26, Selime Beldesi, Bayan, Ev hanımı, 18-34 yaş).

"Korunursa iyi tabi, turist daha çok gelir. Ama devlet bir şey yapmıyor ki, biz de yapmıyoruz. Devlet düzenlese, korusa böyle mi olurdu. Vadiye girin bir kere, kiliselerin içleri pislik, çöp içinde." (YH8, Selime Beldesi, Erkek, Emekli, 35-54 yaş).

"Vadi koruma altında ama yeterli değil. Sadece bekçi var. Kiliselerin duvarları kırılmış durumda. "(YH33, Ihlara Kasabas1, Erkek, Muhtar, 35-54 yaş).

"Geçmişte yaşayan insanların kültürü ve değerlerini tanıtan yapılar korunmalıdır. Tahrip olmayı engeller koruma olunca. Ama koruma vadinin içi için yapılmalı." (YH4, Ihlara Kasabası, Erkek, Boyacı, 18-34 yaş).

Yerel halk Ihlara Vadisi'ndeki kültürel mirasın korunması istemekte ve turizmin devam etmesi için korumanın gerekliliğine inanmaktadır ama koruma amaçlı olarak kendilerinin ne yapması 
gerektiği konusunda bilgiye sahip değillerdir. Ayrıca, Ihlara Vadisi'nin içindeki kiliseler için şu an hali hazırdaki koruma faaliyetlerini yetersiz bulmaktadırlar. Ancak, korumanın sınırlarının vadinin içindeki kiliseler bir başka deyişle turistik değerler ile sınırlı kalmasını istemektedir. Bunun nedeni; yerel halkın, korumanın gerekliliğine inanmakla birlikte devam eden koruma anlayışının kendilerine zarar verdiğini düşünmeleridir (Şekil 6). Bu düşüncelerini şu sözlerle dile getirmektedirler:

"Bizim evlerimize dokunmasinlar. Evlerimizde oturamıyoruz, üstünü onaramıyoruz evlerimizin." (YH18, Belisırma Köyü, Erkek, Boyac1, 35-54 yaş).

"Sit alanı olmasından rahatsızım. Eskiden mă̆aralara davarlarımızı bağlardık, şimdi ne bize faydası var ne başkasına. Ev yaptırmıyorlar, oğlum evlenecek nereye ev yapacă̆ımı düşünüyorum. Evin damı akıyor, 5 senedir yaptıramadım, izin vermiyorlar." (YH14, Belisırma Köyü, Bayan, Ev hanımı, 35-54 yaş).

"Korumanın getirisinden çok götürüsü var. Hayatı zindan ediyorlar bize. Kendi evimizi tamir edemiyoruz, kullanamıyoruz. Sadece korunması gerekenleri korusunlar, evlerimize dokunmasinlar." (YH2, Selime Beldesi, Erkek, İşsiz, 35-54 yaş).

"Ama burası özel çevre oldu, koruma diye bir şey göremiyoruz, sadece evlere dokundurtmuyorlar. Başka bir yanını görmedik özel çevrenin." (YH7, Selime Beldesi, Erkek, Emekli, $55+$ yaş).

"Evlerimizde oturulmuyor genelde, yaptırmıyorlar da. Biz de samanlık, odunluk olarak kullanıyoruz eski evleri. Evleri korumak için bir çalışma yok. Kendi kendine bırakıldl, yok olup gidecek.” (YH29, Yaprakhisar Köyü, Erkek, Çiftçi, 55+ yaş).

Yerel halk, eski evlerin koruma altında olması ve evlerinde herhangi bir tadilata ya da yıkıma izin verilmemesi sebebiyle korumanın kendileri için zararı olduğunu düşünmektedir. Ancak, aslında var olan duruma Ihlara Kasabası'nda Kayaardı Mahallesi'nin muhtarı açıklık getirmektedir:

"Biz eski evleri onarmak istiyoruz ama tapusunu tek kişi üzerine istiyorlar. Ama evler çok varisli. Bir ev 50 bazen 100 kişiye ait. Tüm varisleri bir araya getirip tek tapuya dönüşürmek imkânsız. Sürekli gidiyoruz, eksik evrak var diyorlar. Anıtlar kurulu evlerin fotoğrafinı çekti, beton atmaya izin vermiyorlar. Evi onarmak için proje gerekiyor, proje çizdiriyoruz, o zaman da ev sadece sana ait değil diyorlar. Ihlara'da 40 tane tescilli bina var. $O$ zaman bunlarin hepsinin projesini anıtlar kurulu çizsin, onlar onarsın. Devlet yapsin, halk da ev pansiyon olarak işletsin."

Evlerin onarılabilmesi için restorasyon projesi ve tek kişi üzerine kayıtlı tapu gereklidir. Ancak, evlerin miras yoluyla yıllardır devredilmiş olması ve tapular üzerinde pek çok kişinin hak sahibi olması sebebiyle evler için onarım izni alınamamaktadır. Yerel halk ise, çoğu zaman bilgilendirmenin yetersizliğinden, hiçbir şekilde onarıma izin verilmediğini ve mağdur olduklarını düşünmektedir.

\section{Sonuç ve Tartışma}

$\mathrm{Bu}$ araştırmada, Ihlara Vadisi'nde yaşayan yerel halkın alandaki turizm faaliyetlerinin ekonomik ve sosyal katkısı ile birlikte alandaki kültürel peyzaj değerlerinin korunması konusundaki düşünceleri, alanda gerçekleştirilen görüşmeler çerçevesinde değerlendirilmiştir. Yapılan değerlendirmelere göre şu sonuçlara ulaşılmıştır:

- Ihlara Vadisi içindeki köylerde yaşayan yerel halk, alanda devam eden turizm faaliyetlerinden pay alamamaktadır.

- Halkın büyük bir kısmı geçimlik düzeyde tarım ile uğraşmakta ya da iş amaçlı olarak başka şehirlere/ülkelere göç etmektedir.

- Yerel halk turizm faaliyetlerine katılmak ve ekonomik fayda sağlamak istemektedir.

- Turizm faaliyetleri kapsamında, el sanatları ve yöresel yemek satışı, ev pansiyonculuğu ve yöresel rehberlik yapabileceklerini düşünmektedir. Ancak, bu konularda yeterli bilgiye sahip değildir. 


\section{F. Varnacı Uzun ve M. Somuncu}

- Yerel halk, Nevşehir'in turizmden yüksek pay alması sebebiyle kendilerini olumsuz etkilediğini düşünmektedir.

Gülkal (1999)'a göre de, Ihlara Vadisi'ndeki yerel halk turizmden ekonomik olarak yararlanamadıklarını ve turizmden gelir elde etmek istediklerini dile getirmektedir. Aradan geçen on üç yıllık süreye rağmen, Ihlara Vadisi'ndeki yerel halkın aynı beklentide olması bu bölgedeki turizm faaliyetleri konusunda yeterli girişimin olmadığını ortaya koymaktadır.

Literatürdeki diğer bazı çalışmalarda da; yerel halk, turizmi ekonomik gelişim sağlayan bir araç olarak görmektedir. Ayrıca, turizmin en önemli etkisinin ekonomik etkisi olduğunu düşünmektedir. Yerel halkın turizmin gelişimini desteklemesi ve olumlu ekonomik yararlar sağlaması arasında doğru orantı bulunmaktadır (Andereck vd., 2005; Özdemir ve Kervankıran, 2011; Gürsoy ve Rutherford, 2004; Lepp, 2007). Yapılan çalışmalar, Ihlara Vadisi'nde yerel halkın turizm ile ilgili olarak en fazla turizmin ekonomik yönünden bahsetmesini desteklemektedir. Buradan hareketle, Ihlara Vadisi'ndeki turizm faaliyetleri yerel halka da ekonomik fayda sağlayacak ve halkı turizme katılmasını teşvik edecek şekilde düzenlenmelidir.

- Ihlara Vadisi'ndeki yerel halk, turizme katılım konusunda teşvik ve eğitim istemektedir.

- Ihlara Vadisi'ndeki yerel halk, turizmin gelişimine ve turistlere karşı olumlu tutuma sahiptir.

Çeşitli alanlarda yapılan çalışmalarda da, yerel halkın turizmin gelişimi ve turistler ile ilgili olumlu görüş̧e sahip olduğu görülmektedir (Lepp, 2007; Haley vd., 2005; Zamani-Farahani ve Musa, 2008). Bununla birlikte, Choi ve Murray (2010); turizmin gelişiminde standartların sağlanması için yerel halkın eğitim programları ile desteklenmesini vurgulamaktadırlar.

- Ihlara Vadisi'ndeki yerel halk, kültürel peyzaj değerlerinin vadi içi ile sınırlı olmak şartıyla koruması gerektiğine inanmaktadır.

- Koruma sınırlarının; evlerde tadilata izin verilmediği gerekçesi ile eski evleri kapsamasını istememektedirler.

Literatürde yer alan çalışmalarda da, yerel halk çevresel ve kültürel değerlerin korunmasını desteklemektedir (Besculides vd., 2002; Bestard, 2007; Choi ve Murray, 2010). Ayrica; bazı çalışmalarda yerel halkın turizmin gelişimi ile birlikte çevresel değerlerin bozulacağ taşıdıkları görülmektedir (Bestard, 2007).

Yapılan çalışmalarda ayrıca, paydaşların işbirliği ve turizmin geliştiği bölgelerdeki en önemli paydaş konumunda olan yerel halkın turizme katılımının gerekliliğine dikkat çekilmektedir (Aronsson, 2000; Swarbrooke, 1999; Aas vd., 2005; Byrd vd., 2009; Yoon, 2002; Akşit, 2007; Akova, 2006). Varnacı Uzun ve Somuncu (2011)'e göre; bölgedeki bir diğer paydaş grubunu oluşturan turistler de, Ihlara Vadisi'nde yerel halkın turizme katılımı konusunda olumlu görüşe sahiptir.

Ihlara Vadisi'ndeki turizm faaliyetleri, ekonomik ve sosyal kalkınmayı sağlarken, kültürel peyzaj değerlerinin etkili bir yönetimle korunmasını sağlayacak, sürdürülebilir turizm yaklaşımıyla düzenlenmelidir. $\mathrm{Bu}$ kapsamda, mutlaka yerel halkın turizm plan ve faaliyetlerine katılımı sağlanmalıdır.

\section{Kaynaklar}

Aas, C., Ladkin, A. and Fletcher, J. 2005. Stakeholder Collaboration and Heritage Management. Annals of Tourism Research, 32(1), 28-48.

Akova, O. 2006. Yerel Halkın Turizmin Etkilerini Algılamalarına Ve Tutumlarına Yönelik Bir Araştırma. Akademik İncelemeler Dergisi, 2(1), 1-34.

Aksaray İl Kültür ve Turizm Müdürlüğü. 2008. Aksaray İli Ören Yerleri Gelir ve Ziyaretçi İstatistiği. Aksaray.

Aksaray İl Kültür ve Turizm Müdürlüğü. 2009. Aksaray İli Ören Yerleri Gelir ve Ziyaretçi İstatistiği. Aksaray.

Aksaray İl Kültür ve Turizm Müdürlüğü. 2010. Aksaray İli Ören Yerleri Gelir ve Ziyaretçi İstatistiği. Aksaray. 


\section{Kültürel Peyzajın Korunması ve Turizm İlişsisi Bağlamında Yerel Halkın Görüşleri: Ihlara Vadisi Örneği}

Akşit, S. 2007. Doğal ortam duyarlılı̆̆ı açısından sürdürülebilir turizm. Erciyes Üniversitesi, Sosyal Bilimler Enstitüsü Dergisi, 23(2007/2), 441-460.

Alaeddinoğlu, F. 2007. Van halkının turisti ve turizmi algılama şekli. Coğrafi Bilimler Dergisi, 5 (1), 1-16.

Andereck, K.L., Valentine, K.M., Knopf, R.C. and Vogt, C.A. 2005. Residents' Perceptions of Community Tourism Impacts. Annals of Tourism Research, 32(4), 1056-1076.

Aronsson, L. 2000. The Development of Sustainable Tourism. Continuum, Great Britain.

Avcıkurt, C. 2003. Turizm Sosyolojisi: Turist-Yerel Halk Etkileşimi. Detay Yayınları, Ankara

Ballesteros, E.R. and Ramirez, M.H. 2007. Identity and community-Reflections on the development of mining heritage tourism in Southern Spain. Tourism Management, 28(2007), 677-687.

Baykan, E. 2007. Turizmin yerel kültür üzerindeki etkilerinin yöre halkı tarafindan algılanması (Ürgüp yöresine yönelik bir uygulama). Basılmamış yüksek lisans tezi, Gazi Üniversitesi, Eğitim Bilimleri Enstitüsü, Turizm İşletmeciliği Eğitimi Bilim Dalı, Ankara.

Besculides, A., Lee, M.E. and McCormick, P.J. 2002. Residents' Perceptions of the Cultural Benefits of Tourism. Annals of Tourism Research, 29(2), 303-319.

Bestard, A.B. and Nadal, J.R. 2007. Modelling environmental attitudes toward tourism. Tourism Management, 28(2007), 688-695.

Butler, R. 1999. Sustainable Tourism: A State of the Art Review. Tourism Geographies, 1, 7-25.

Byrd, E.T., Bosley, H.E. and Dronberger, M.G. 2009. Comparisons of stakeholder perceptions of tourism impacts in rural eastern North Carolina. Tourism Management, 30(2009), 693-703.

Choi, H.C. and Murray, I. 2010. Resident attitudes toward sustainable community tourism. Journal of Sustainable Tourism, $18(4), 575-594$.

Çetin, T. 2010. Cumalıkızık köyünde kültürel miras ve turizm algısı. Millî Folklor, 22(87), 181-190.

Dal, N. ve Baysan, S. 2007. Kuşadası'nda kıyı kullanımı ve turizmin mekânsal etkileri konusunda yerel halkın tutumları. Ege Coğrafya Dergisi, 16 (2007), 69-85.

Deery, M., Jago, L. and Fredline, L. 2012. Rethinking social impacts of tourism research: A new research agenda. Tourism Management, 33(2012), 64-73.

Dyer, P., Gursoy, D., Sharmaa, B. and Carter, J. 2007. Structural modeling of resident perceptions of tourism and associated development on the Sunshine Coast, Australia. Tourism Management, 28(2007), 409-422.

Dyre, D. 2010. Linking Tourism Resources and Local Economic Development: A Spatial Analysis in West Virginia. Master of Science, Davis College of Agriculture, Natural Resources and Design At West Virginia University.

Eagles, P.F.J., McCool, S.F. ve Haynes, C.D. 2002. Sustainable Tourism in Protected Areas. World Commission on Protected Areas, Best Practice Protected Area Guidelines Series:8, Spain.

Emekli, G. 2001. Bergama’nın Turizm Coğrafyası ve Turizmin Sosyo-Ekonomik Etkileri. Bergama Belediyesi Kültür Yayınları, İzmir.

Fowler, P.J. 2003. World Heritage Cultural Landscapes 1992 -2002. UNESCO World Heritage Series Papers:6, France.

Gebhard, K., Meyer, M. ve Roth, S. 2008. Criteria for Sustainable Tourism fort he Three Biosphere Reserves: Aggtelek, Babia Gora and Sumava. Ecological Tourism in Europe, Bonn, Germany.

Gülkal, Ö. 1999. Ihlara (Kapadokya) Özel Çevre Koruma Bölgesi ve Yakın Çevresi Örneğinde; Koruma-Kullanma Dengeli Planlamaların Oluşturulmasında Kriterlerin Saptanması. Basılmamış Doktora Tezi, Çukurova Üniversitesi, Peyzaj Mimarlığı Anabilim Dalı, Adana.

Gürler, G. 2007. Göreme Tarihi Milli Parkı Ve Yakın Çevresinin Jeolojik Miras Açısından Değerlendirilmesi. Jeoloji Etüdleri Dairesi Başkanlığ 1 , MTA: 10989, Ankara.

Gürsoy, D. ve Rutherford, D. G. 2004. Host Attitudes Toward Tourism An Improved Structural Model, Annals of Tourism Research, 31(3), 495-516.

Gürsoy, D., Jurowski, C. and Uysal, M. 2002. Resident Attitudes A Structural Modeling Approach, Annals of Tourism Research, 29(1), 79-105. 


\section{F. Varnacı Uzun ve M. Somuncu}

Haley, A.J., Snaith, T. and Miller, G. 2005. The Social Impacts of Tourism A Case Study of Bath, UK. Annals of Tourism Research, 32(3), 647-668.

Jimura, T. 2011. The impact of world heritage site designation on local communities- A case study of Ogimachi, Shirakawamura, Japan. Tourism Management, 32(2011), 288-296.

Kaya, L.G. 2002. Cultural landscape for tourism. Zonguldak Karaelmas Üniversitesi, Bartın Orman Fakültesi Dergisi. 4 (4): 54-60.

Kuvan, Y. and Akan, P. 2005. Residents' attitudes toward general and forest-related impacts of tourism: the case of Belek, Antalya. Tourism Management, 26(2005), 691-706.

Lepp, A. 2007. Residents' attitudes towards tourism in Bigodi village, Uganda. Tourism Management, 28(2007), 876-885.

Nicholas, L. N., Thapa, B. And Ko, Y. J. 2009. Residents' Perspectives of a World Heritage Site The Pitons Management Area, St. Lucia. Annals of Tourism Research, 36(3), 390-412.

Özdemir, M.A. ve Kervankıran, İ. 2011. Turizm ve turizmin etkileri konusunda yerel halkın yaklaşımlarının belirlenmesi: Afyonkarahisar örneği. Marmara Coğrafya Dergisi, 24(2011), 1-25.

Somuncu, M. ve Yiğit, T. 2009. Göreme Milli Parkı Ve Kapadokya Kayalık Sitleri Dünya Mirası Alanı'ndaki Turizmin Sürdürülebilirlik Perspektifinden Değerlendirilmesi. V. Ulusal Coğrafya Sempozyumu Bildiriler Kitabı: 387-402, 1617 Ekim 2008, Ankara.

Stone, L.S. and Stone, T. M. 2010. Community-based tourism enterprises: challenges and prospects for community participation; Khama Rhino Sanctuary Trust, Botswana, Journal of Sustainable Tourism, 19(1), 97-114.

Strickland-Munro, J.K., Allison, H.E. and Moore, S.A. 2010. Using Resilience Concepts to Investigate the Impacts of Protected Area Tourism on Communities. Annals of Tourism Research, 37(2), 499-519.

Swarbrooke, J. 1999. Sustainable Tourism Management. CABI Publishing, United Kingdom.

TÜİK. 2011. Adrese Dayalı Nüfus Kayıt Sistemi Veri Tabanı, 2011.

UNESCO. 1998. Natural Sacred Sites. Cultural Diversity and Biological Diversity International Symposium, 22-25 September 1998, Paris.

UNESCO. 1999. The World Heritage Convention and Cultural Landscapes in Africa Expert Meeting. 9-14 March 1999, Tiwi, Kenya

Uslu, A. ve Kiper, T. 2006. Turizmin kültürel miras üzerine etkileri: Beypazarı/Ankara örneğinde yerel halkın farkındalığı. Tekirdağ Ziraat Fakültesi Dergisi, 3 (3): 305-314.

Varnacı Uzun, F. ve Somuncu, M. 2010. Kültürel Peyzaj Değerlerinin Yerel Kalkınma İçin Önemi: Ihlara Vadisi Örneği. VI. Ulusal Coğrafya Sempozyumu. Bildiriler Kitabı: 355-365, 03-05 Kasım 2010, ANKARA.

Varnacı Uzun, F. ve Somuncu, M. 2011. Ihlara Vadisi’ni Ziyaret Eden Turistlerin Yerel Halkın Turizme Katılımına İlişkin Görüşleri. KMÜ Sosyal ve Ekonomik Araştırmalar Dergisi, 14 (22), 113-118.

Williams, J. and Lawson, R. 2001. Community Issues and Resident Opinions of Tourism. Annals of Tourism Research, 28(2), 269-290.

WTO. 1993. Sustainable Tourism Development: A Guide for Local Planners. World Tourism Organization, Madrid.

Yoon, Y. 2002. Development of a Structural Model for Tourism Destination Competitiveness from Stakeholders' Perspectives. Doctor of Philosophy. Faculty of the Virginia Polytechnic Institute and State University.

Zamani-Farahani, H. and Musa, G. 2008. Residents' attitudes and perception towards tourism development: A case study of Masooleh, Iran. Tourism Management, 29(2008), 1233-1236. 